\title{
Burocracia e a revolução gerencial — a persistência da dicotomia entre política e administração
}

Revista do

Serviço

Público

Ano 48

Número 1

Jan-Abr 1997

\author{
Humberto Falcão Martins
}

"Escrever sobre burocracia é denúncia e esperança. [...] Se precisamos entender a burocracia, precisamos também aprender a superá-la."

(Bresser Pereira \& Prestes Motta, 1980)

Este ensaio trata essencialmente da integração entre política e administração, atributo presente, desde os clássicos gregos, no ideal do bom governo e questão central nas discussões contemporâneas sobre a boa governança. Pretendo, neste ensaio, analisar este atributo no contexto mutante da burocracia contemporânea, que tende a incorporar formas de organização e gestão pública oriundas da chamada "revolução gerencial".

O texto está estruturado em cinco segmentos. Nos dois primeiros segmentos busco delinear uma interpretação weberiana do problema central da burocracia: a dicotomização entre política e administração. Este delineamento baseia-se numa problematização mais genérica, no contexto teórico da governança contemporânea, e noutra mais específica, no contexto da modernização da administração pública brasileira. Especificamente no primeiro segmento proponho um quadro conceitual que visa servir de referência à análise da integração entre política e administração. No terceiro segmento, procuro desenvolver uma caracterização da forma básica de integração entre política e administração de um modelo (ideal) de administração pública preconizado pela revolução gerencial, a partir de outros paradigmas de administração pública reconstituídos da literatura de administração pública: um ortodoxo, um liberal, outro empreendedor. No quarto segmento, argumento que os modelos de administração pública preconizados pela revolução gerencial
Humberto Falcão Martins é mestre em administração pública pela FGV/EBAP e especialista em políticas públicas e gestão governamental no Ministério da Administração Federal e Reforma do Estado 
apresentam, embora de forma diferenciada, o mesmo caráter

dicotomizante entre política e administração típico da burocracia. Finalmente, no sexto segmento ensaio algumas reflexões sobre a validade da revolução gerencial, e sua contribuição para a experiência brasileira, e sobre o advento de uma revolução pósgerencial, principalmente no que concerne ao papel do conhecimento científico no campo da administração pública na busca de formas mais integrativas de política e administração.

\section{O problema da burocracia}

\subsection{Resgatando Max Weber do problema epistemológico da burocracia}

Weber é um eterno incompreendido. Sua sociologia é tão complexa e, por vezes, contraditória, que torna impossível a existência de um weberianismo. De fato, há weberianos, nunca weberianistas (CHACON, 1988). Weber tem lugar cativo no pensamento sociológico: forma, com Marx e Durkheim, o tripé do pensamento sociológico. Nesta perspectiva, sua contribuição ao domínio das ciências sociais, em geral, e da ciência política, em particular, é rica e relativamente bem explorada - embora inesgotada. $\mathrm{O}$ primeiro problema da burocracia é de natureza epistemológica: a sociologia política de Weber raramente conta com uma apreciação organizacional condizente com a sua complexidade. Isto se reflete, grosso modo, em duas perspectivas: a da sociologia das organizações e a da administração.

Na perspectiva da sociologia das organizações estão aqueles que se basearam quer numa leitura predominantemente - em alguns casos, exclusivamente- organizacional da relação de disfuncionalidade entre organização burocrática (seus atributos morfológicos) e fenômeno burocrático (burocracia enquanto forma de dominação racional-legal); quer os que (de forma não excludente) se inspiraram na interpretação de Weber procedida por PARONS (1937) - cuja leitura teria sido grandemente influenciada pela sua própria sociologia estrutural-funcional (LeIVESLEy e outros, 1994). Dentre estes estão, principalmente, MERTON (1959), que explora na morfologia burocrática típica uma tendência ao deslocamento de objetivos em direção a regras, normas e interesses próprios; Michels (1949), que identifica uma tendência à oligarquização segregatória do poder intraburocrático; Von Mises (1944), que explora o caráter antiinovador, reforçador 
do status quo, da estrutura burocrática; SElzNick (1964), que denuncia o paradoxo da organização burocrática, ou as influências da organização informal em torno de seus objetivos próprios; Gouldner (1954), que identifica uma relação entre mecanismos de supervisão e controle e uma tendência à acomodação em torno de padrões mínimos; e CrozIER (1979), que desmascara o círculo vicioso da burocracia, sua incapacidade estrutural em autocorrigirse de forma sistêmica, ancorando-se em estratégias conservadoras e formalistas de autoproteção. O problema comum destas perspectivas é que se baseiam na presunção de que existe um tipo burocrático, um modelo típico de organização burocrática; aceitam como válido o modelo utilizado por Weber, não raro tomado como proposição normativa, e direcionam sua crítica à inviabilidade organizacional deste modelo típico, tendencialmente autoorientado. A crença básica é de que o problema da burocracia é essencialmente organizacional, mesmo o problema político da burocracia é organizacional, relacionado à morfologia burocrática literalmente descrita por Weber e restrito aos limites internos da organização burocrática.

Na perspectiva da administração estão os autores que delimitam uma escola weberiana no pensamento administrativo, inferem suas prescrições administrativas e, enfim, qualificam sua contribuição para o campo da administração. Assim, para KAST \& Rosenweig (1970), Weber forma, ao lado de Taylor e Fayol, o terceiro pilar da escola clássica da administração; ETZIONI (1976) o considera um precursor da escola estruturalista; MARCH \& SIMON (1967) incluem Weber no rol dos arquitetos da organização formal, no qual figuram anatomistas clássicos como Gullick e Urwick - apesar de reconhecerem que a burocracia comporta diferentes níveis de análise —; e BLAU \& ScotT (1970) consideram Weber um precursor da escola clássica, notadamente do princípio do one best way (o tipo-ideal burocrático) para a eficiência. Muitos teóricos da administração ainda consideram Weber, com poucas variações, o pai da burocracia (sic).

Estas duas perspectivas têm dois traços em comum: uma sistemática incompreensão da burocracia no contexto da sociologia política de Weber e uma confusão acerca dos atributos epistemológicos dos tipos-ideais. O primeiro traço resulta numa compreensão organizacional da burocracia, desconexa de uma visão da burocracia em Weber, no conjunto de sua obra. Falham os sociólogos das organizações e os administradores ao tentar conceituar a burocracia a partir da organização burocrática, porque "antes de mais nada, burocracia é poder” (Bresser Pereira \& Prestes-Motta, 1980). 
O segundo traço apóia-se na confusão entre organização buro-

crática e no tipo ideal descrito por Weber, que de recurso puramente metodológico, no qual não cabe identificação com a realidade (FREUND, 1975), é transformado em modelo prescritivo (BERTERO, 1981). PARSONs (1937), aliás, demonstra seu descontentamento com o termo ao afirmar que a organização burocrática descrita no tipo ideal não tem nada de ideal: se fosse ideal não seria tipo, porque estes derivam-se da realidade empírica; se fossem tipos não seriam ideais, porque estes derivam-se da pura abstração. O tipo ideal burocrático é, aliás, dos mais pobres utilizados por Weber: seus elementos podiam ser encontrados na ciência da administração alemã de então. A validade epistemológica deste recurso, largamente utilizado por Weber em outras abordagens, não está em questão, senão sua utilização para a compreensão do fenômeno burocrático.

O problema epistemológico da burocracia, do qual Weber é, até hoje, vítima, é que a burocracia, enquanto fenômeno de poder, prescinde de uma organização burocrática típica. Dito de outra forma, não há organização burocrática típica, senão aquela que se baseia, de uma forma bastante flexível no que se refere à sua morfologia, num sistema formal-impessoal.

\subsection{O problema político da burocracia}

O problema central da burocracia, segundo Weber, não é organizacional ou administrativo; é político. Max Weber não fez teoria das organizações; fez sociologia política. O destaque da abordagem weberiana está onde a burocracia se coloca no seu quadro de pensamento social (Wrong, 1970). Weber foi pioneiro em apontar a problemática da desintegração entre política e administração na perspectiva do estado moderno. Segundo seu argumento, o surgimento do estado burocrático implicaria a renúncia de responsabilidade pela liderança política e na usurpação das funções políticas por parte dos administradores. A questão por detrás desta problemática é o contraste, a distinção e a tensão entre a racionalidade substantiva da busca de interesses e a racionalidade instrumental-formal do exercício da autoridade.

“O progresso da burocratização na própria administração estatal é um fenômeno paralelo da democracia [...] Decerto devemos lembrar sempre que a expressão democratização pode ser enganosa. A própria demos, no sentido de uma massa inarticulada, jamais governa associações maiores; ao invés disso é governada, e sua existência apenas modifica a forma pela qual os líderes políticos são selecionados e a medida de 
influência que a demos, ou melhor, que os círculos sociais em seu meio podem exercer sobre o conteúdo e direção das atividades administrativas [...] Democratização, no sentido aqui pretendido, não significa necessariamente uma participação cada vez mais ativa dos governados na autoridade da estrutura social. Isso pode ser um resultado da democratização, mas não é necessariamente o caso [...] A expressão, geralmente imprecisa, democratização não pode ser usada aqui, à medida que é entendida como a minimização da capacidade governativa do funcionário público em favor do maior domínio direto possível da demos, que na prática significa os respectivos líderes partidários de demos. $\mathrm{O}$ aspecto mais decisivo no caso é o nivelamento dos governados em oposição ao grupo dominante e burocraticamente articulado, que por sua vez pode ocupar uma posição bastante autocrática, tanto de fato quanto na forma [...] Daí ter esse processo significado um progresso da burocracia e, ao mesmo tempo, da democratização passiva [...]" (WEBER, 1974:261-3).

Weber não propõe uma teoria funcional da integração entre política e administração. No nível organizacional, acredita na superioridade técnica da burocracia, mais amparada no caráter histórico-universal da racionalização instrumental, que nas características do tipo ideal burocrático que utiliza. No nível político, a sociologia política de Weber aceita o conflito entre política e administração, razão substantiva e instrumental, fatos e valores, como insolúvel, embora passível de equilíbrio mediante o exercício efetivo da liderança política. No contexto da moderna democracia de massa, a dicotomização entre política e administração é um imperativo da escala e da complexidade. A democracia de massas impõe, ao contrário da democracia direta, que os governados influenciem as decisões executivas de seus governantes por meio da representação política. Fundamentalmente, a sociologia política de Weber põe em evidência os riscos da desintegração entre política e administração, processo de inversão da racionalidade burocrática, cuja tendência ao absolutismo burocrático ameaça a legitimidade do Estado.

"Esse [...] problema parecia ser o maior aos olhos de Weber [...] sob a dominação legal, o exercício diário da autoridade fica nas mãos da burocracia. Mesmo o sucesso na disputa por votos em debates parlamentares e nas eleições legislativas pode resultar em nada se não for acompanhado de um controle efetivo sobre a implementação administrativa. Quando não se consegue tal controle, a burocracia usurpa o processo de decisão política de acordo com sua tendência fundamental ... de transformar todos os problemas políticos em problemas administrativo" (BENDIX, 1986: 338; trecho grifado referese à MANHeim, 1949:105). 
A despeito de sua morfologia organizacional, apenas incidentalmente é a burocracia em Weber compreendida no seu significado sociológico original, segundo o qual figura como uma forma moderna de dicotomização entre política e administração, quer pelo isolamento da administração em relação às premissas valorativas da ação pública, quer pelo seu reverso, a usurpação, pela administração, das funções políticas. Mas o problema político da burocracia não é a dicotomização em si, mas a sua extensão e as suas formas de integração ou dicotomização entre política e administração, mais ou menos funcionais relativamente à governança. Esta questão se relaciona, certamente, às formas organizacionais da burocracia, mas não está restrita ao seu domínio.

\subsection{A integração entre política e administração no contexto da governança contemporânea}

O cenário da governança ${ }^{1}$ contemporânea caracteriza-se por uma espécie de influência burocrática sobre a prática política e de influência política sobre a prática burocrática que não indicam, a princípio, uma integração funcional entre política e administração, conforme sugerida por ABERBACH e outros (1981), ao descrever um processo de politização da administração e burocratização da política como a consagração de um padrão de relações entre políticos e burocratas nas poliarquias contemporâneas.

A desintegração entre política e administração verifica-se, primeiro, porque a prática da política burocrática não repousa exclusivamente nos atributos estruturais da mecânica democrático-representativa, senão da crescente predominância decisória da burocracia inserida neste contexto (LindBloom, 1980). Segundo, porque tampouco a politização da administração é o resultado de novos critérios de relevância assimilados e processados pela burocracia pública, conforme um padrão de racionalidade prática e valorativa, mas o resultado de um processo em que a ação estatal típica do estado de direito, condicionada aos seus processos e imperativos racionais-legais, torna-se crescentemente inconfiável (Offe, 1984). Política e administração, ou sistema político-representativo e agências de governo, enquanto arenas institucionais, integram-se ou dicotomizam-se de diferentes formas à medida que competem ou cooperam tanto na identificação e agregação de interesses da sociedade civil, quanto na formulação e implementação das políticas públicas. O diagrama 1 procura ilustrar este quadro: 
Diagrama 1

Relação política - Administração no contexto da governança contemporânea

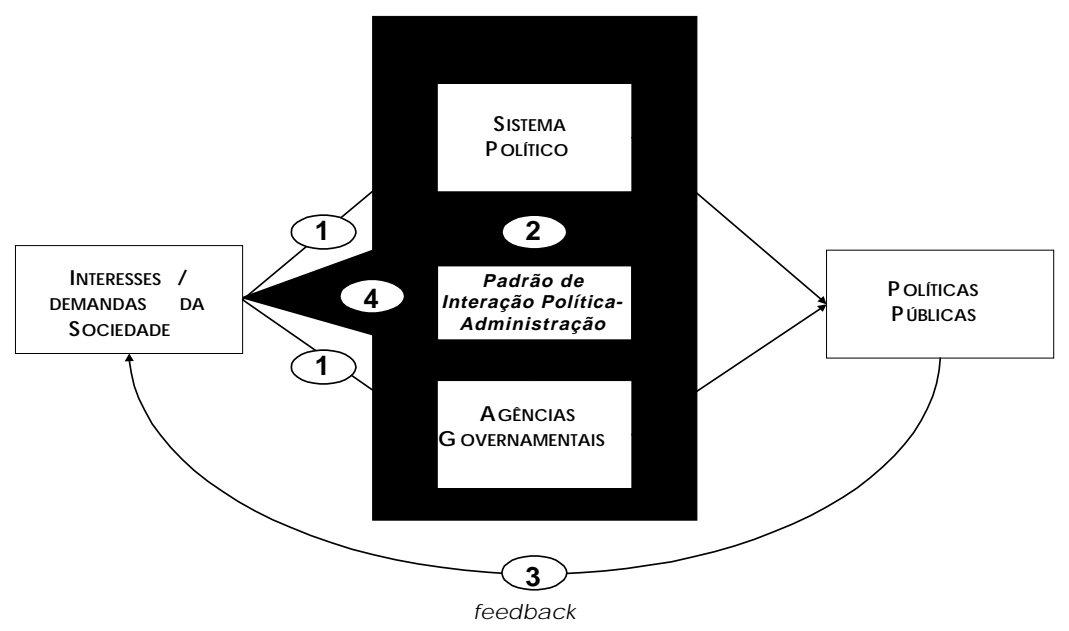

A questão, conforme se apresenta, é estabelecer um padrão de interação entre política e administração que atenda simultaneamente aos requisitos de inserção social e regulação política no alcance de níveis de autonomia relativa que são negociados nas relações contratuais (de delegação ou representação de interesses) entre os principais atores da ação pública. Esta visão sistêmica tanto da governança, quanto, inserida no seu contexto, da integração entre política e administração, pode ser melhor qualificada no âmbito das abordagens do agente x principal e da racionalidade tridimensional contraditória.

$\mathrm{Na}$ perspectiva do paradigma do agente $\mathrm{x}$ principal, segundo o qual as transações sociais entre atores na esfera tradicional do Estado e do mercado podem ser enfocados a partir de uma relação tipo contratado (agente) e contratante (principal) (MeLo, 1996), os requisitos de inserção e regulação figuram claramente. Primeiramente, são tratados enquanto interdependência sistêmica de três espécies de relação: entre Estado (burocracia e sistema político) e agentes econômicos (representado pelo círculo 1 no diagrama 1); entre políticos e burocratas (círculo 2); e entre cidadãos e políticos (círculo 3) (Przeworski, 1996). Embora essencialmente interdependentes, estas três categorias de relações, principalmente entre políticos e burocratas, representam três vetores de um conflito por autonomia relativa entre os principais atores com os quais a burocracia se relaciona (área triangular à qual o círculo 4 está sobreposto no diagrama 1). A própria autonomia do Estado tende a ser vista como uma resultante desta interação (PrZEworski, 1995). 
O modelo da racionalidade tridimensional contraditória, de OfFE (1984), é, para fins de exploração das relações entre política e administração, análogo-complementar ao paradigma do agente x principal. De acordo com modelo de Offe, a ação administrativa correta é uma resultante de três vetores de racionalidades contraditórias: conformação com o caráter formal-legal do estado de direito (burocracia); adequação às demandas da clientela (interesses localizados da sociedade civil, ou inserção); e adequação às concepções políticas sobre valor (regulação política). Claro está, neste esquema, o requisito de integração entre política e administração baseadas na autonomia relativa inserida e regulada. A legitimidade da ação pública repousa no processamento desta tripla racionalidade.

Um aspecto da integração entre política e administração que estas abordagens não esclarece é a possibilidade de conflito entre inserção social e regulação política da autonomia burocrática relativa. Trata-se da possibilidade de um alto grau de autonomia incrustada (embedded autonomy) do ponto de vista da capacidade governativa relacionada à implementação de projetos de desenvolvimento, caracterizada por um alto grau de cooperação de atores privados (EvANs, 1989), mediante fraca supervisão política. Nesse caso, a ação pública, embora inserida, torna-se dicotomizante.

Por outro lado, a questão da autonomia politicamente regulada mediante baixa inserção social está na base do equilíbrio dinâmico ao qual se referiu EISENSTADT (1978). Eisenstadt define o equilíbrio burocrático como uma situação na qual a burocracia, dotada de um grau mínimo de autonomia, atende ao interesse público quando está supervisionada por legítimos titulares de poder. O que subjaz a esta visão de burocracia representativa é o requisito, exclusivo, da regulação política. O autor define, complementarmente, duas situações de quebra do equilíbrio da regulação burocrática: a burocratização, um ganho de autonomia pelo qual o interesse público é restrito por interesses próprios ou particularistas; e a desburocratização, uma situação típica de perda de autonomia que leva à captura do interesse público por alianças subservientes essencialmente predatórias e parasíticas firmadas entre a burocracia e segmentos externos da sociedade civil e do sistema político. O pólo da desburocratização ilustra uma situação de inserção disfuncional, porque o que subjaz ao equilíbrio burocrático de Eisenstadt é a idéia de que a regulação política é auto-suficiente para assegurar a legitimidade dos sistemas burocráticos. Esta idéia é dicotomizante.

$\mathrm{O}$ aspecto mais relevante da integração entre política e administração é a necessária relação de funcionalidade recíproca entre inserção e regulação. A regulação política sobre a burocracia é um empecilho à sua tendência de auto-orientação. A inserção social, 
mediante a orientação para o usuário, é uma forma de equilíbrio necessária à regulação não apenas da burocracia, mas da política e de sua influência sobre a burocracia. Numa condição de equilíbrio burocrático, de integração entre política e administração, ambas são indissociáveis. O diagrama 2 ensaia, num único quadro de referência, os dois continua de análise da burocracia no contexto da governança contemporânea: por um lado, a burocratização da política e a politização da administração e, por outro, os requisitos de inserção e regulação:

\section{Diagrama 2}

\section{Integração política - Administração: autonomia inserida e regulada}

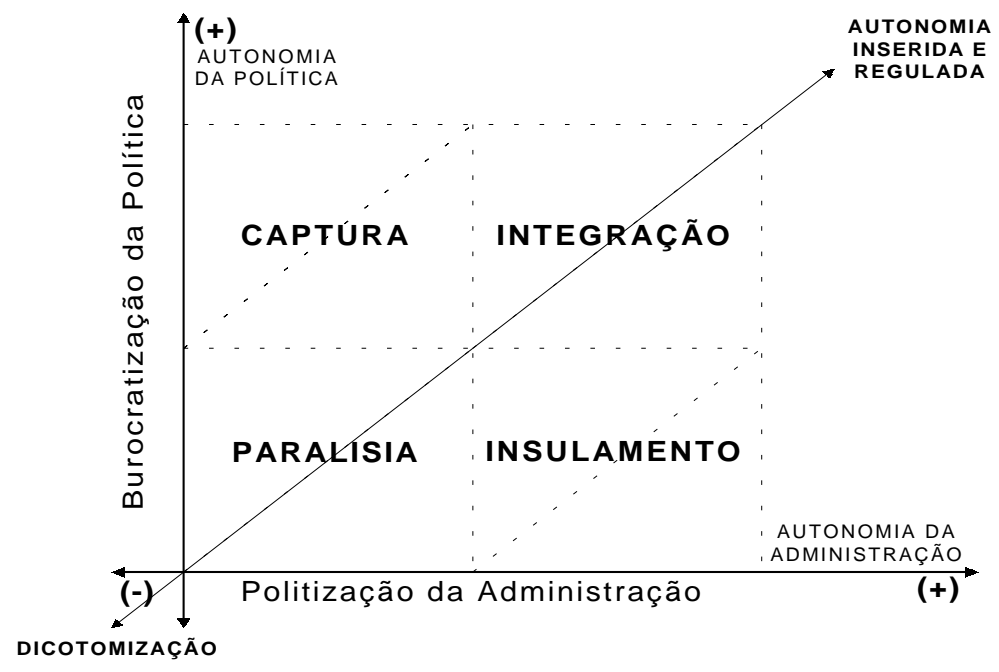

Os quadrantes representam formas típicas de integração/ dicotomização entre política e administração. Os eixos representam pólos tendenciais. No quadrante integração caberiam, por exemplo dois tipos de integração entre política e administração: um de integração competitiva, caso típico da poliarquia presidencialista norte-americana, onde o congresso compete com e influencia a administração; outro de integração cooperativa, caso das poliarquias parlamentaristas européias, onde a administração é formada de dentro do parlamento. O mesmo eixo comporta, conforme o esquema, no sentido descendente, duas situações típicas de desintegração: captura, situação de pouca autonomia burocrática e excessiva regulação política, padrão tipicamente clientelista; e insulamento, situação de excessiva autonomia burocrática e baixa regulação política, que 
pode resultar em auto-orientação ou alianças espúrias do tipo anéis

burocráticos. O quadrante esquerdo inferior representa uma situação de paralisia, na qual a ação burocrática perde autonomia, não se insere e não está politicamente regulada.

O problema da burocracia é a dicotomização entre política e administração. O problema da dicotomização entre política e administração no contexto da governança contemporânea é que as formas burocráticas engendradas na sua operação falham no desenvolvimento de adequados recursos organizacionais e institucionais de inserção e regulação política. Com efeito, boa parte das buropatologias vislumbradas pelos sociólogos das organizações - no sentido das disfunções oriundas da excessiva burocratização (CAIDEN, 1994) - estavam referidas à não regulação política ou à nãoinserção social. Outro problema é que estas buropatologias estão localizadas mais fora do que dentro das organizações burocráticas, não em decorrência exclusiva da sua formatação organizacional, mas da forma pela qual se relaciona com seu meio externo no contexto da governança. É à luz deste requisito que suas formas organizacionais devem ser analisadas.

\subsection{O problema da organização "pós-burocrática"}

A organização pós-burocrática tem sido colocada como uma promessa de felicidade organizacional, de libertação dos efeitos da burocracia sobre pessoas e sociedade, porque sua formatação organizacional seria ou poderia ser diferente da aludida por Weber. Warren Bennis (1973) está dentre os precursores desta idéia já em 1966 na sua obra Changing Organizations, reeditada em 1973 sob o título de Beyond Bureaucracy. A idéia, invariavelmente baseada no mesmo argumento, fez escola: Mosher (1971), ToflLER (1980) e DRUCKER (1985) aprimoraram-na, nesta perspectiva, ressaltando a necessidade de organizações mais flexíveis, mais temporais (adhocracia), mais adequadas à dinâmica ambiental de turbulência, incerteza e transformações e à ecologia humana. A tradição organizacional pós-burocrática se baseou no falso pressuposto de que o problema da burocracia era exclusivamente organizacional.

"Alguns autores restringem o conceito de burocracia a um tipo de sistema social rígido, centralizado, que se amolda quase perfeitamente ao tipo ideal de burocracia descrito por Max Weber. Para esses autores bastaria que o sistema social se afastasse um pouco desse modelo, que se descentralizasse, que se flexibilizasse para deixar de ser uma organização burocrática. [...] Todo sistema social administrado segundo critérios racionais e hierárquicos é uma organização burocrática. Haverá organizações burocráticas mais flexíveis ou mais rígidas, mais formalizadas ou menos, mais ou menos autoritárias. 
[...] Assim, a crítica administrativa, ao afirmar as fontes de ineficiência da organização burocrática, ou que estamos passando para uma fase de organizações pós-burocráticas, na verdade, legitima ideologicamente a burocracia, enquanto poder e dominação que é”. (BRESSER Pereira \& PREstes Mota, 1980:12-13; 224)

A utopia pós-burocrática é tão intrincada quanto o dilema no qual é tradicionalmente colocada a burocracia e, sobretudo, mal interpretada, no enfoque weberiano: ou se submete a burocracia instrumental ao controle político, incrementando-se o exercício da política, ou se cria uma burocracia que não seja puramente instrumental, mas integrada e permeada pela racionalidade do sistema político (regulação) e da sociedade (inserção), não pela sua própria racionalidade - alternativa esta timidamente explorada por Weber apenas no que respeita à regulação política, o que lhe rendeu a pecha de pessimista e determinista. A utopia pós-burocrática é o sentido correto de superação das disfunções burocráticas na sociedade burocrática. O ideal de liquidação da burocracia é o ideal de uma burocracia articulada com a racionalidade substantiva de forma funcional, o que no contexto da governança democrática significa inserção e regulação.

Por outro lado, o fatalismo weberiano, ou a negação da utopia pós-burocrática, consiste em se estabelecer um continuum conceitual entre a inversão da racionalidade da ação burocrática e o processo de racionalização, de caráter histórico-mundial (OFFE, 1984), atribuindo-se à burocracia um pathos metafísico (GOULDNER, 1964). Com efeito, a má-leitura de Weber leva ao erro recorrente de, além de se considerar o tipo ideal burocrático uma receita para a organização da máquina burocrática independentemente de condições externas peculiares, considerar a dominação burocrática um critério estrutural irreversível para as sociedades futuras, cuja transcendência independe de uma racionalidade integrativa superior.

Em resumo, a partir do significado de burocracia em Weber, uma burocracia weberiana teria como atributo principal e necessário o caráter dicotomizante entre política e administração, entre racionalidade instrumental e racionalidade política — independentemente de sua morfologia organizacional. Nesta perspectiva, a superação da crise da administração pública através de uma alternativa pretensamente pós-burocrática se restringe à modernização das formas burocráticas enquanto burocracia, não se relacionando, como seria recomendável, ao equacionamento dialético da questão, qual seja à busca de paradigmas de administração pública que integrem a racionalidade política e a racionalidade instrumental numa racionalidade superior (GUERREIRO RAMOS, 1983; 1981; OFFE, 1984), uma racionalidade inserida e regulada. 
O problema da organização pós-burocrática é que ela não existe conforme proposta pela crítica exclusivamente administrativa. A construção pós-burocrática exclusivamente organizacional é meramente estética; tal como a arte, uma promesse de bonheur. A organização pós-burocrática existe à medida que logra equacionar as disfunções políticas da burocracia no contexto social, solução que depende dos requisitos de inserção e regulação.

\section{O problema da modernização da administração pública brasileira}

A dicotomização entre política e administração é um traço distintivo da modernização da administração pública brasileira. A trajetória modernizante da administração pública brasileira representa a tentativa de substituição da administração patrimonial pela burocrática. Este processo tem sido marcado pelas descontinuidades e contraditoriedades político-administrativas do Estado, que impuseram um caráter dissociativo às tentativas de implementação de uma burocracia pública no Brasil.

O padrão burocrático brasileiro tem sido construído segundo dois requisitos dicotômicos: autonomia insulada, que se opõe à inserida; e regulação autocrática, que se opõe à regulação político-representativa. Primeiramente, a gramática do insulamento burocrático tornou praticamente possível não apenas a construção burocrática, mas a própria construção nacional e o desenvolvimento decorrente (NUNES, 1996). Segundo, a trajetória da modernização da administração pública brasileira revela, na perspectiva do Estado, uma difícil compatibilização e uma relação de disfuncionalidade recíproca entre política e administração, entre burocracia e democracia. Ora tentou-se consolidar uma burocracia, racionalizando-se funcionalmente a administração, à revelia da Política e à custa da democracia, ora tentou-se descaracterizar o caráter funcional da burocracia pública pretensamente até em nome da democracia; ora obstaculizada, ora estimulada pelos agentes do Estado e da política nacional.

\subsection{A modernização "daspeana” no regime do Estado Novo}

A implementação do Estado Intervencionista da Era Vargas marca o advento de um Estado Administrativo no Brasil 
Público, DASP, criado em 1938 a partir do Conselho Federal do Serviço Público para ser o principal agente modernizador, promoveu uma verdadeira revolução na administração pública, empregando tecnologia administrativa de ponta e profissionalizando o serviço público segundo o mérito. Este processo se refletiu na diferenciação de órgãos, no estabelecimento de normas reguladoras da ação estatal e empresarial e em significativas mudanças organizacionais, ações e normas racionalizadoras de métodos e processos administrativos segundo os padrões tipicamente burocráticos então em voga na literatura administrativa (WAHRLICH, 1983).

A crítica mais comum à disfuncionalidade do modelo daspeano concentra-se, todavia, no seu caráter hermético, de sistema insulado pautado linearmente nos inputs do regime de Vargas sob boa carga discricionária. Uma consequiência mais imediata é a própria hipertrofia do DASP no contexto do Estado, extrapolando a função de órgão central de administração, ainda que de cunho normatizador e executor direto, e assumindo características de agência central de governo com poderes legislativos, que abrigaria, de fato, a infra-estrutura decisória do regime do Estado Novo (Wahrlich, 1983). Como consequiência, teria a ação do DASP criado um divórcio entre a administração e o quadro social e econômico, sem expressão política pela via democrática (CuNHA, 1963).

Efetiva ou não, do ponto de vista do desenvolvimento econômico gerado a partir do Estado, a modernização daspeana foi essencialmente dissociativa: implementou um estado administrativo ao largo da política, em reação à mesma, embora o regime usasse de expedientes típicos da velha política, tal como o clientelismo (Schwartzman, 1987). O insulamento burocrático daspeano e o regime do Estado Novo constituíram-se, respectivamente, as formas de autonomia insulada e regulação autocrática neste período.

\subsection{A redemocratização e o advento da "administração paralela"}

O período compreendido entre 1945 e 1964 representa o desdobramento das estruturas institucionais do Estado, tendo como pano de fundo o panorama político e o retorno à democracia. $\mathrm{O}$ desmonte institucional do Estado Novo, a tentativa de reintrodução do dirigismo estatal no novo governo Vargas, a adaptação institucional às estratégias desenvolvimentistas estatais no governo JK e os ajustes decorrentes da disfuncionalidade burocrática e da 
crise política e econômico-financeira do Estado nos governos Quadros e Goulart têm em comum a incapacidade ou inconveniência em se aumentar o nível de racionalidade da administração pública pautadas numa finalidade predominantemente clientelista.

O governo Dutra desmontou parcialmente o aparato governamental do Estado Novo. Embora tenha desativado de pronto as estruturas ad hoc de controle geradas a partir da guerra, sua inclinação liberalizante não dispensou os antigos colaboradores de Vargas, necessários à operação das novas máquinas estaduais, e a nova aparelhagem governamental, grandemente aumentada e sob a influência direta dos políticos (SKIDMORE, 1982).

De volta ao poder, Vargas ensaiou, em 1952, uma profunda reforma administrativa, o que não implicava o soerguimento do DASP, senão abarcava, em razoável amplitude, a organização macrogovernamental e algumas questões estruturais relativas ao funcionalismo. No entanto, a reforma, que chegou à condição de Projeto de Lei, jamais foi posta em prática, até porque o imobilismo decorrente do seu ocaso o impediu de fazê-lo.

Tendo como embrião as missões americanas no início dos anos 40, o modelo da planificação tem seu apogeu nos 50 anos em 5 do governo $\mathrm{JK}$, desfalecendo com o fracasso das reformas de base no governo Goulart. As grandes transformações no Estado e na sociedade geraram uma maior demanda sobre a máquina governamental pública, impondo a adoção de soluções rápidas e ágeis (sob a forma de conselhos, grupos executivos e comissões), que, sob o argumento da temporariedade, tornaram-se estruturas paralelas aos órgãos já existentes. Em que pesem as ações da Comissão de Estudos e Projetos Administrativos (CEPA) e da Comissão para a Simplificação Burocrática (COSB), ambas de 1956, voltadas à racionalização de métodos e processos administrativos, havia um marcante hiato entre os propósitos do Estado desenvolvimentista e suas estruturas ad hoc e a condição operacional da burocracia permanente (IANI, 1977). Fundamentalmente, a dinâmica da política nacional nesse período, no pleno exercício da democracia, abriu espaço para a barganha instrumental, atendendo às conveniências políticas de empregar e nomear, para compor e coligar, práticas que resultaram em crescimento de órgãos e quadros e destruição do sistema do mérito, fazendo predominar uma racionalidade de barganha política clientelista (LAMBERT, 1970).

O governo Quadros concentrou-se programaticamente em dois principais pontos críticos: o funcionalismo e o esquema adocrático implantado por JK (SKIDMORE, 1982). Esta estratégia, fortemente influenciada pela personalidade do presidente Quadros não contribuiu, todavia, para a efetiva realização de reformas estruturais, até mesmo devido à brevidade de seu mandato. 
No governo Goulart, a comissão Amaral Peixoto (posteriormente transformada em ministério extraordinário) foi criada para propor diretrizes de um processo de reforma administrativa, com o propósito de promover um ajuste à volta do regime presidencialista. As recomendações da referida comissão foram de grande valia, mas no período seguinte. Analogamente às reformas estruturais propostas no governo Goulart, a reforma administrativa não se realizou.

Este período representa mais uma etapa do padrão dicotômico de modernização. A autonomia insulada da administração paralela contrastava com a paralisia regulada da administração tradicional. Não obstante a administração paralela tenha logrado, em muitos casos inserção social, a regulação à qual a burocracia paralisada foi submetida requer qualificação. A redemocratização não resultou em regulação política sobre a burocracia, senão na regulação fisiológica e clientelista. $\mathrm{O}$ sistema administrativo estatal esteve, neste período, aberto às influências da política representativa, desinteressada na regulação política dos esforços modernizantes e interessada quer em negociar os resultados das instâncias mais modernas, quer em lucrar com a paralisia das mais atrasadas.

\subsection{O regime militar e sua “administração para o desenvolvimento"}

Um dos compromissos básicos do regime implantado em 1964 era o melhoramento da maquinaria da administração pública. $\mathrm{O}$ Decreto-Lei no 200, marco inicial deste movimento, estabeleceu uma radical reestruturação na administração pública federal, baseada em princípios como planejamento, organicidade, centralização decisória e normativa; e desconcentração (descentralização funcional, no texto legal), notadamente por intermédio da administração indireta, quer para atuar em setores produtivos da economia, quer para o cumprimento, com mais flexibilidade, de funções típicas de Estado.

As reformas iniciadas em 1967 visavam operacionalizar o modelo de administração para o desenvolvimento, baseado na consolidação burocrática de um Estado forte, voltado para o desenvolvimento econômico, cuja característica principal foi o predomínio da racionalidade funcional, emanada da tecnoestrutura indispensável à manutenção do regime autoritário, cujo viés dissociativo consistia na predominância do planejamento econômico como núcleo decisório de governo e no crescimento desordenado da burocracia governamental indireta (BERTERO, 1984; RAmos, 1981). As estruturas de planejamento especializaram-se em formular planos e perderam a noção política do planejamento, 
necessária a sua eficácia. Já o crescimento desordenado da administração indireta tornaria virtualmente impossível a retomada do controle governamental, quer mediante o regime de supervisão ministerial, quer mediante a instituição de mecanismos de controle econômico-financeiro atrelados ao planejamento (LimA JR. \& ABRANCHES, 1987).

Este período representou uma inequívoca racionalização funcional da administração pública, embora concentrada na administração indireta, e portadora de disfuncionalidades próprias. $\mathrm{O}$ fato é que neste período o aparelho do Estado sofreu um vigoroso processo de modernização administrativa, graças à ruptura que promoveu entre política e administração, atributo do modelo decisório tecnocrático e pelo controle dos meios de produção pela tecnoburocracia. A própria noção de tecnoestrutura supõe uma relação funcional entre Estado e sociedade alheia à política, em parte, pelo espaço preenchido pela força do regime, em parte devido a um processo de esvaziamento da elite política (BRESSER PEREIRA, 1977a e 1977b; Martins, 1974; Collier, 1982). As altas taxas de crescimento, por seu turno, davam legitimidade ao sistema autoritário: "O povo, desiludido com os erros e com o oportunismo dos 'políticos', parecia resignar-se, pelo menos temporariamente, com o domínio dos tecnocratas sob tutela militar" (SKIDMORE, 1988: 388).

O desenho institucional tecnocrático implementado pelo regime militar foi essencialmente dicotomizante. Por um lado, insulou o Estado da política, estabeleceu um padrão de regulação tecnocrática. Por outro, e como conseqüência, não logrou preserválo da própria influência patrimonialista tecnocrática, que através de formas como a dos anéis burocráticos e estratégias de ganhos crescentes auto-orientados (rent-seeking) representaram um padrão de autonomia insulada mediante inserção auto-orientada.

\subsection{A Nova República e a "Era da Desmodernização"}

Esta fase inicia-se com o advento da Nova República, e estende-se ao final do governo Itamar Franco, na qual inicia-se um acentuado processo de deterioração da administração pública, decorrente não só de disfunções herdadas do modelo tecnocrático, mas, principalmente, do efeito deletério da política patrimonialista sobre a administração pública presente tanto na incapacidade ou na inconveniência em se restabelecer a racionalidade funcional do sistema quanto na implantação de padrões de irracionalidade política com finalidades patrimonialistas.

A Nova República herda um modelo tecnocrático de administração pública que dava sinais de exaustão, não apenas pela 
inexperiência em lidar com a racionalidade da política e dos políticos, mas cujas condições de operação eram decrescentes. O que estava em jogo era, ademais, não apenas a transição política, mas uma transição do poder patrimonial, onde as alianças que suportavam os anéis burocráticos passariam por uma revisão política. Os desafios de resgatar a capacidade da burocracia pública em formular e implementar políticas sociais e direcionar a administração pública para a democracia foram sobrepostos pelo imperativo em tornar a administração pública um instrumento de governabilidade, loteando áreas e cargos em busca do apoio político necessário à superação das dificuldades da instabilidade política da transição. As promessas e as insubsistentes tentativas de se reformar a administração pública, num período de fragilidade das instituições, incertezas e, sobretudo, imaturidade política, caíram por terra através do jogo fisológico.

Paralelamente, o avanço da crise econômica impôs a prática de ajustes conjunturais na economia e a adoção de um modelo de ajuste do setor público de natureza predominantemente fiscal que resultou numa fase de intensa desmodernização, ou seja, uma quase completa desarticulação do sistema de formulação e implementação de políticas públicas, sucateando a intelligentsia administrativa do Estado e o patrimônio social constituído em períodos anteriores, parcialmente dilapidado pelas políticas compensatórias de cunho populista e demagógico (SANTOS \& Ribeiro, 1993).

Houve, no governo Sarney, um peso relativamente maior das políticas sociais na ação governamental, mas a tentativa de implantação de um Estado Social no Brasil, estampada principalmente na Constituição de 1988, foi malsucedida (Velloso, 1994). A incapacidade ou a inconveniência de se reformar a administração foi, sobretudo, política, agravada pela instituição de casuísmos constitucionais que desorganizaram o sistema de carreira, a previdência do serviço público, sua estrutura e seu regime funcional.

O governo Collor herdou os escombros da máquina estatal dilacerada pela prática patrimonialista da Nova República, cuja reconstrução era item programático de governo. A reforma administrativa do governo Collor fechou-se ao debate político, foi formulada mediante um baixo grau de consenso social e implementada de maneira autoritária, inconseqüente e combativa (NuNEs, 1992). O lema de moralização do serviço público foi rapidamente desmoralizado por evidências de privatização do Estado no bojo da maior estrutura patrimonialista da história da República, o esquema PC. Não obstante disfuncional, a reforma Collor foi dissociativa, avessa à política, embora o final do governo Collor tenha sido marcado por uma fase de intensa barganha instrumental com segmentos partidários em busca de apoio. 
A reforma administrativa do governo Itamar Franco caracterizou-se, inicialmente, pela reversão da reforma administrativa Collor, o que implicou a reorganização da macroestrutura governamental nos moldes da Nova República, inclusive no que se refere à finalidade de barganha política por escalões de governo. Fundamentalmente, o governo Itamar Franco manteve-se incapacitado de iniciar um processo de ajuste estrutural na administração pública, onde a barganha instrumental fortalecia-se pelos momentos delicados do impeachment.

Neste período de redemocratização o insulamento tecnoburocrático deu lugar ao político-corporativo, baseado em alianças político-partidárias perfeitamente encaixadas na prática fisiológica em busca de recursos e influência sobre a administração pública. Por outro lado, uma aliança patrimonialista com a burocracia miúda se deu pela via do corporativismo, num ambiente marcado pela crescente politização do serviço público e, conseqüentemente, pela conquista de privilégios condizentes com a condição de estamento, categoria e classe social, mas não com a racionalidade burocrática das carreiras. As tentativas de modernização da administração pública, notadamente no bojo do plano Collor, foram alheias, senão contra, a política, indistintamente se se tratasse de política fisiológica ou da decorrente da democracia. Em ambos os casos verifica-se o fenômeno da dissociação entre política e administração pública no ambiente democrático: o padrão de regulação política foi essencialmente fisiológico e clientelista; o padrão de inserção foi essencialmente corporativo, auto-orientado.

\subsection{O caráter dicotômico da modernização da administração pública brasileira}

A trajetória modernizante da administração pública brasileira representa, nas palavras de Simon Schwartzman,

"um difícil dilema, que colocaria de um lado a administração racional e técnica, associada aos regimes fortes e autoritários, e de outro a administração politizada, deficiente e desmoralizada, que pareceria ser um atributo da democracia e da participação social" (SCHWARTZMAN, 1987:58).

O atual estágio de percepção e intervenção a respeito da crise do Estado tem suscitado a proliferação de alternativas de reconstrução e evolução burocrática no ambiente democrático. A administração pública brasileira está diante de uma oportunidade única na sua trajetória: modernizar-se na democracia. Isto implica o grande desafio de se integrar meios de regulação política com meios de inserção social. Não obstante, o debate acerca das alternativas 
emergentes não tem se intensificado com os necessários vigor e aprofundamento tanto no plano acadêmico quanto no político.

Se por um lado, os atributos intrínsecos e as tecnicalidades de modelos e estratégias de inovação gerencial no setor público são exaltados pelos seus segmentos propositores, por outro, algumas questões básicas têm permanecido apagadas no terreno da crítica construtiva: em que extensão a busca da excelência burocrática ou pós-burocrática - conforme atualmente proposta pode afigurarse dicotomizante? Em que extensão a busca de modelos não-estatais de formulação e implementação de políticas públicas, em especial aqueles que se colocam no âmbito do terceiro setor (público nãoestatal) estarão ou deverão estar imunizados contra as influências da política, embora socialmente inseridos? Como equacionar os requisitos de regulação política e inserção social no atual contexto da governança brasileira? Respondê-las é algo complexo e requer considerações em casos específicos - o que não se insere nos propósitos deste trabalho. Mas buscar melhor enunciá-las é possível e necessário à efetiva implementação das inovações gerenciais propostas.

\section{Modelos de administração pública: uma tentativa de caracterização da "revolução gerencial"}

Os modelos de administração pública apresentados a seguir são reconstituições a partir da literatura corrente em administração pública, cujos dois primeiros estão sugeridos em STILlman (1991). Minha intenção é caracterizar um modelo ortodoxo que tem sido objeto de crítica e transformações mediante a implementação de dois outros, um liberal, outro empreendedor. A presente análise crítica não procura recusá-los ou sugerir a extensão da sua aplicabilidade: os modelos reconstituídos são construções de tipos ideais. O objetivo de sua elaboração e contraposição é meramente analítico: refletir sobre a orientação e o arcabouço de um contexto de modernização da burocracia verificado na prática, a chamada revolução gerencial.

\subsection{Uma visão ortodoxa da administração pública}

A visão ortodoxa da administração pública é a que mais se aproximou originariamente da concepção do tipo ideal utilizado por Weber, embora tenha evoluído no que respeita a sua morfologia. Tende a prescrever reformas centradas no emprego e aprimoramento de meios como fatores de eficiência para o fortalecimento institucional de organizações e poderes (O’Toole, 1984). A visão 
ortodoxa da administração pública remonta às primeiras iniciativas de se estruturar a administração pública americana, por volta de 1870, como reação ao patrimonialismo, e, posteriormente, em 1939 pela comissão Brownlow, o que assentou as bases do welfare state norte-americano contemporâneo e alcançou sólida tradição na disciplina (Rosenbloom, 1971). Seu patrono poderia ser Woodrow Wilson, taxativo em afirmar que questões administrativas não são questões políticas (WILson, 1887), seguido pelos fundadores da administração pública moderna, a partir das obras de Luther Gulick, Louis Brownlow e Leonard White, e aperfeiçoados por diversos autores contemporâneos, dos quais destacam-se Paul Volcker, Robert Denhardt, Edward Jennings, Robert Reich, Steven Cohen, James Stever e Charles Goodsell.

O pensamento ortodoxo tem evoluído no sentido de prescrever reformas visando à consolidação de uma administração pública atuante, baseada na expansão efetiva do Estado e na construção de instituições fortes (institution building) para maximização de respostas aos desafios sociais, com as seguintes características:

1) controle federal central sobre as atividades de planejamento, coordenação, direção, formulação e implementação de políticas públicas;

2) ênfase no aumento global da capacidade de implementação de políticas nas várias esferas do Estado;

3) preenchimento de cargos-chave por funcionários de carreira, profissionais especializados, treinados e equipados com tecnologias gerenciais e métodos e dotados de recursos orçamentários;

4) ênfase na capacidade gerencial do servidor público como incentivo à inovação;

5) limitação na interferência política sobre a administração, mediante contratos de gestão flexíveis, inclusive por meio de arranjos organizacionais experimentais;

6) responsabilidade da base para o topo, versus direção do topo para a base.

7) ênfase nos cidadãos usuários e clientes;

8) prioridade na administração de cargos e salários públicos;

9) incremento dos programas de recrutamento em pólos de excelência profissional.

Do ponto de vista organizacional, trata-se de uma proposta de aumento da produtividade do executivo federal, cujo principal aspecto é a ênfase na sólida construção institucional de organizações estatais para o aprimoramento da gestão pública. Os teóricos desta vertente desenvolveram, ao longo das últimas seis décadas, um vasto arsenal técnico e metodológico centrado no aumento da eficiência dos sistemas burocráticos públicos. 


\subsection{Uma visão liberal da administração pública}

Uma visão liberal da administração pública contrapõe-se à visão ortodoxa no sentido de que propõe um modelo de administração pública baseado na lógica do mercado. No nível microorganizacional, reduz a utilidade das organizações públicas a finalidades de mercado, quer no sentido macroeconômico, quer no que respeita à avaliação da relação custo-benefício. Propõe o aumento da capacidade de julgamento político do burocrata, mas enfoca a questão ética da burocracia sob a ótica da conformação às orientações político-partidárias.

No plano macroorganizacional, baseia-se na adequação do equipamento administrativo do Estado às finalidades mínimas do estado de direito, seguindo valores políticos dominantes. A proposta liberal de administração pública inverte a visão de burocracia pública e subverte-a à lógica do mercado, posicionando-se contra o Estado.

Seus princípios inspiram-se no ideal de intervenção estatal dos economistas clássicos e dos adeptos da chamada teoria da escolha pública (public choice), inspirados na filosofia liberal de Adam Smith e no pensamento econômico da Escola Austríaca do século XIX. Este pensamento - onde atualmente destacam-se as correntes monetarista e neoliberal, dentre os quais incluem-se, principalmente, Milton Friedman, George Stigler e Gary Becker e os principais teóricos da escolha pública, James Buchanan, Gordon Tullock, William Niskanen e Vincent Ostrom- atingiu sua notoriedade máxima nos meios acadêmicos e políticos dos anos 80 , período ilustrado com evidências empíricas como a queda do mundo socialista e a crise do welfare state.

Esta abordagem partiu de uma imagem altamente negativa da burocracia pública: negligência ao interesse público; excesso de gastos; desperdício; falta de interesse direto do funcionalismo na obtenção de resultados; monopólio de funções; adoção, pelos burocratas, das políticas mais convenientes aos seus interesses próprios; etc. Prescrevem um modelo de modernização baseado na imposição de severos limites à ação pública, numa clara tentativa de conter, não superar a patologia burocrática que denuncia. São as seguintes as características de seu modelo:

1) redução do tamanho do Estado, via privatização, terceirização e voluntarismo;

2) descentralização e desconcentração da esfera federal para a estadual e municipal;

3) desregulamentação radical;

4) forte liderança política do topo para a base;

5) extrema lealdade a programas de governo; 
6) preenchimento de cargos-chave da administração por indicados compromissados com a agenda política partidária, em vez de funcionários de carreira;

7) papel tecnicalista do administrador público: restrito a tarefas administrativas, como administração de contratos, serviços e normas;

8) emprego de técnicas de administração por resultados nas instâncias de execução, como administração por objetivo, prêmios e incentivos de produtividade; e

9) processo decisório centrado em análises de custo-benefício.

Do ponto de vista meramente gerencial, este modelo se destaca pela ênfase nos resultados e o caráter questionador da gestão pública sobre os custos e os benefícios das opções públicas, para quem e qual interesse público os benefícios estão direcionados. Por outro lado, compreende aspectos polêmicos:

a) estilo gerencial autoritário e hierarquicamente rígido;

b) ocupação de cargos-chave segundo critérios sobretudo políticos;

c) desestímulo à administração participativa; e

d) síndrome da privatização e desregulamentação, que pode levar à omissão em áreas onde a ação pública é necessária.

Mas a crítica principal é que este modelo parece se colocar contra o Estado, bem como colocar a política contra a administração pública, tamanha sua crença fatalista na impossibilidade de os sistemas burocráticos tornarem-se instâncias capazes de promover a vontade política de uma maneira mais integrada e funcional.

\subsection{Uma visão empreendedora da administração pública}

Um terceiro modelo de administração pública alcançou, de uma forma incisiva, lugar central nas discussões acadêmica e política no campo da administração pública nos anos 90. O empreendedorismo público baseia-se na prescrição de técnicas originariamente empresariais, tais como reengenharia, gestão da qualidade total, redimensionamento, etc., à gestão de organizações públicas. Abordagens originariamente empresariais, inclusive qualidade e reengenharia, são recomendadas ao ambiente da administração pública baseadas no argumento de que há pressões crescentes para o aprimoramento dos serviços e a redução de despesas, mediante restrições orçamentárias (Dobyns \& CRAWFOR-MASON, 1994). São, com efeito, instrumentais com potencial racionalizador, embora sua eficácia em cenários organizacionais públicos careça de avaliação, adaptações de contexto, e controle finalístico. 
O exemplo mais popular é a proposta de reinvenção do Estado, um compêndio de empreendedorismo público. Osborne \& Gaebler proclamaram a reinvenção do Estado baseados na superação da era progressiva do estado americano, onde se verificou a implantação do modelo ortodoxo de administração pública. A nova era, pósprogressiva, se caracteriza pela competição global, pela integração da comunicação, pela economia centrada na tecnologia e em nichos de mercado, características, segundo os autores, incompatíveis com a lógica operacional da burocracia tr adicional. Sugerem, então, um novo modelo de governança, centrado na produção de bens e serviços públicos de alta qualidade, orientados para os clientes de uma maneira empresarial, segundo estes dez princípios (OSBORNE \& GAEBLER, 1994):

1) preferência a alternativas de produção externa de bens e serviços: terceirização, parcerias governo-sociedade civil, voluntarismo etc.;

2) gestão participativa de programas e projetos com clientes;

3) estímulo à competição interna e externa;

4) desregulamentação interna, simplificação organizacional e clarificação de papéis e missões;

5) avaliação e financiamentos baseados em resultados;

6) imagem do cliente como consumidor: com direito a escolhas, pesquisas de preferências e atitudes, treinamento de atendimento e formulários de sugestões;

7) criação de centros de resultados financeiros, promovendo ação pública rentável;

8) antevisão estratégica de serviços;

9) descentralização e desconcentração: controle hierárquico versus autoridade, desenvolvimento de equipes (team building), gestão participativa, cooperação trabalhadores-gerentes, círculos de controle de qualidade e programas de desenvolvimento gerencial; e

10) atingimento das finalidades governamentais através da reestruturação do mercado.

Por um lado, esta visão de Estado empreendedor se constitui uma alternativa crítica ao modelo liberal de administração pública minimalista, porque prega um Estado atuante, uma administração pública ativista, cujo alcance é, todavia, inspirado por critérios de eficiência empresarial. Por outro lado, o paradigma do empreendedorismo público se coloca como uma alternativa crítica ao modelo burocrático ortodoxo, porque prescreve, em larga e irrestrita escala, métodos e técnicas de administração de empresas. No âmbito microorganizacional, propõe a adoção de tecnologia gerencial de ponta. No âmbito macroorganizacional, prescreve um setor público como empreendedor seletivo, baseado nos critérios empresariais, até mesmo competitivos dentre si e com o setor privado. 
Tomada no seu conjunto, a proposta de Osborne \& Gaebler é um composto de velhas e novas, boas e más idéias rotuladas coletivamente de "governo reinventado" (Goodsell, 1993). Do ponto de vista gerencial, engloba dúvidas relativas aos limites entre autonomia, participação e responsabilidade, entre competição e paralelismo, entre liberdade e suspeita, entre cidadãos e consumidores, entre direitos e escolha, entre interesse público e viabilidade de mercado. Fundamentalmente, um problema básico do empreendedorismo público é o elevado risco de empresarização da administração pública, conforme proposto por Osborne \& Gaebler. Afinal, o que se dá com base no contexto local — onde a distância entre cidadão e consumidor é menor — torna-se, segundo sua crítica mais recorrente, irreconciliável com a democracia numa escala federal, porque peca em captar a verdadeira dimensão política do Estado quando reduz o caráter finalístico de sua ação à utilidade de mercado (Terry, 1993; Hart \& Scott, 1982; Gibbs, 1994; Moe, 1994).

\subsection{Uma reconstituição da administração pública da "revolução gerencial"}

Holmes \& SHAnd (1995) apresentam uma caracterização genérica dos modelos de administração pública da revolução gerencial:

a) caráter estratégico ou orientado por resultado do processo decisório;

b) descentralização;

c) flexibilidade;

d) desempenho crescente;

e) competitividade interna e externa;

f) direcionamento estratégico;

g) transparência e cobrança de resultados (accountability); etc. Mas uma caracterização mais criteriosa requer a identificação de elementos dos três arquétipos de administração pública reconstituídos anteriormente no contexto da revolução gerencial.

A revolução gerencial é um conjunto de respostas e questionamentos à crise do Estado conforme se afigurou na Grã-Bretanha e Estados Unidos nos anos 80. A caracterização padrão da crise do Estado engloba alguns pontos recorrentes que se interrelacionam em diferentes medidas:

a) fim do desenvolvimentismo pós-guerra, pelo fim de Bretton Woods, as crises do petróleo, as crises de liquidez e a instabilidade do mercado financeiro internacional, os novos requisitos de integração competitiva da globalização, etc.;

b) crise do welfare state keynesiano, pelas disfunções e desvantagens da intervenção estatal na garantia do bem-estar ou da 
estabilidade econômica, relativamente aos atributos do mercado, conforme defendido pelas correntes de inclinação neoliberal a partir dos anos 70;

c) disfunções burocráticas ou crise do modo de implementação estatal de serviços públicos; e, dentre outras,

d) ingovernabilidade: sobrecarga fiscal, excesso de demandas e crise de legitimidade.

$\mathrm{O}$ sucedido na Europa e nos Estados Unidos previamente à revolução gerencial se enquadra na macro referência acima. A Inglaterra, em particular, consolidara um padrão de welfare state de caráter universalista e um padrão de administração pública de orientação mais ortodoxa - Whitehall, que, já entre 1966 e 1968, segundo a Comissão Fulton, apresentava disfuncionalidades. Experimentava, ademais, uma aguda mudança demográfica que sobrecarregaria o estado (ricamente demonstrada por PoLlitT, 1990) e um debate político que culminou com a ascensão dos conservadores e suas práticas reformistas, inicialmente mais desestatizantes - rolling back the state - que racionalizadoras. Os Estados Unidos que consolidaram um padrão residual de welfare state - mas um sólido padrão de warfare state - e de burocracia federal se debatiam com questões semelhantes, mas cujas respostas liberais foram de cunho ainda mais descentralizantes. A revolução gerencial eclodiu neste contexto bastante sumariado.

As respostas administrativas a esta situação foram, todavia, diferentes nos casos da Grã-Bretanha e dos Estados Unidos. No contexto inglês sucederam-se três categorias de soluções administrativas: o gerencialismo puro, o consumerism e o modelo do Public Service Oriented (PSO). O gerencialismo puro, mais desestatizante que racionalizador, consistia na reação inicial à crise do estado inglês, parte de uma estratégia de eficiência centrada no aumento de produtividade e na redução de custos e de pessoal. Visava estabelecer uma definição de responsabilidades de funcionários e organizações públicas, suas missões e objetivos. Fundamentalmente, apoiava-se numa ética de valorização do custo dos recursos - value money. Dentre as ações práticas do gerencialismo puro figuram a racionalização orçamentária, avaliação de desempenho, administração por objetivo descentralização e delegação de autoridade. Dentre as principais críticas que se colocam ao modelo estão a desatenção à efetividade, decorrente do foco na eficiência - que rendeu, inclusive, o rótulo de neo-taylorista - e a despolitização das ações estatais (PollitT, 1990).

O consumerism consistiu numa segunda resposta, uma reorientação do gerencialismo puro mais voltada à racionalização tendo como ponto central a questão da satisfação das necessidades 
dos cidadãos/consumidores de serviços públicos. A ênfase deste modelo é uma estratégia de qualidade, a ser controlada pelo programa Citizen's Charter, cujos resultados apoiavam-se em medidas tais como descentralização, estímulo à competitividade, modelos contratuais flexíveis e direcionados para a qualidade. O problema básico que se colocou com relação a este modelo foi o conflito entre interesses do consumidor e do cidadão, que envolve limites da cobrança de resultados (accountability), questões de eqüidade e efeitos perversos da competitividade — como os efeitos soma zero.

Estas críticas motivaram a concepção de um terceiro modelo não tipicamente gerencial, que prega a reconstrução da esfera pública, sob a denominação de public service oriented. Ao contrário dos anteriores, que se concentravam no "como?" da ação estatal, este modelo preocupa-se no “o que?”. Dessa forma, propõe uma revalorização da política na definição das finalidades estatais, aumento da accountability, participação, transparência, eqüidade e justiça. Este movimento baseia-se numa visão coletiva do cidadão, enfoca a esfera pública como um locus de aprendizado social e prega o aprimoramento da cultura cívica do cidadão, burocrata e político. O que é mais interessante, é que, ao mesmo tempo em que procura retomar o conceito clássico de público, não descarta a tecnologia gerencial desenvolvida pelos modelos anteriores (ABRUCIO, 1996).

O contex to americano caracteriza-se pelo hibridismo entre uma tendência gerencialista, que está presente na cultura empresarial e nos ideais de fundação do estado federado, e outra tendência mais ortodoxa, mais aproximada do tipo ideal burocrático utilizado por Weber, que tem desempenhado um papel de barreira a formas patrimonialistas de administração pública, como a patronagem. No contexto americano, a redução da transferência de recursos federais para estados, numa radicalização da descentralização, gerou uma resposta nas instâncias subnacionais bastante identificada com suas bases culturais gerencialistas, suscitando o movimento do reinventing government, que originariamente municipal e estadual, foi posteriormente extrapolado para o âmbito federal — conforme expressa o National Performance Review.

Não obstante a proliferação semântica, vários modelos de administração pública da chamada "revolução gerencial" cabem nos três paradigmas reconstituídos, se bem que predominantemente no liberal, caso do gerencialismo puro, e no empreendedor, caso do consumerism. Aliás, como tendência geral, a revolução gerencial tem evoluído através de um shifting do paradigma liberal para o empreendedor, se bem que mediante algumas características típicas da administração pública ortodoxa - caso do public service oriented. 
Mas em que medida isto significa um avanço no que se refere à busca de formas integrativas entre política e administração? Em que extensão isto significa um passo adiante no equacionamento e encaminhamento de soluções ou paliativos para o problema da burocracia?

\section{4. "Revolução gerencial" e burocracia: a persistência da dicotomia}

Os paradigmas de administração pública abordados, nos quais se enquadra, em diferentes graus e medidas, a administração pública da revolução gerencial, colocam-se em sentidos divergentes: o ortodoxo, centra-se na construção institucional de uma administração pública no molde do tipo ideal utilizado por Weber, entre o estado e a burocracia, distante da política; o liberal, desestatizante e desregularizante, centra-se numa administração pública mínima sob estreito controle político do mercado; e o empreendedor, centra-se na adoção de métodos de gestão e avaliação empresariais aplicados a organizações públicas. O diagrama 3 ilustra a divergência destes enfoques:

\section{DIAGRAMA 3}

\section{Orientação dos paradigmas de administração pública}

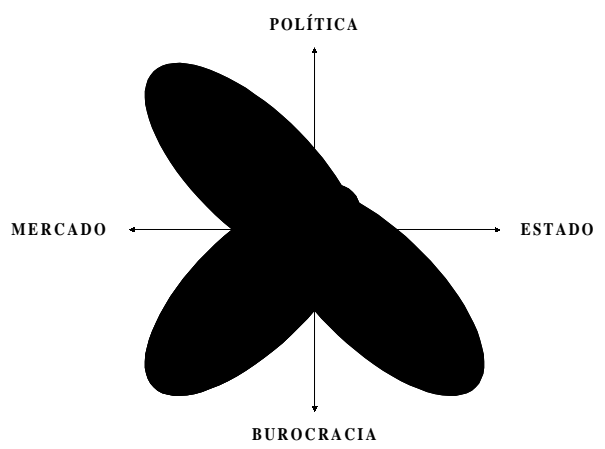

Sob esta perspectiva, uma primeira conclusão é a de que os três modelos analisados são dicotomizantes. O modelo ordodoxo concentra-se na racionalidade da administração burocrática legal, representando o isolamento das premissas da ação administrativa no sistema político, que detém o feedback da clientela e dos grupos políticos, no que respeita ao atendimento de suas necessidades ou identificação com seus valores. O modelo ortodoxo baseia-se exclusivamente na regulação política; não admite inserção social direta explícita. A autonomia burocrática é minimizada pela regulação política. Seu caráter dicotomizante está representado no diagrama 4: 


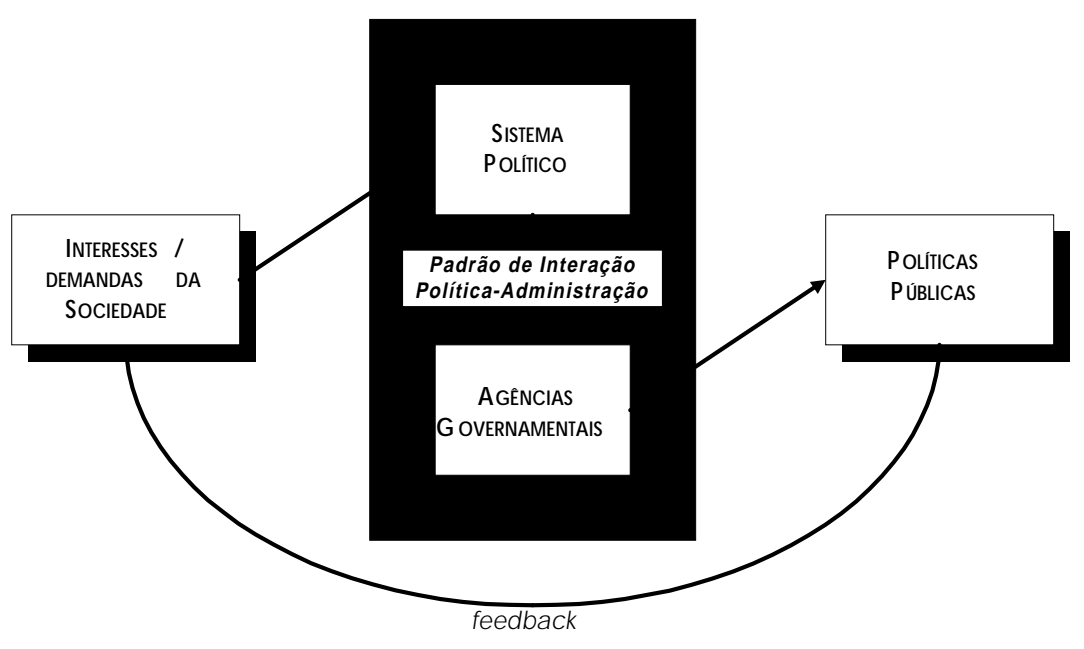

O modelo liberal concentra-se na racionalidade do consenso político e da adequação às finalidades pela via do mercado, o que impõe ao sistema administrativo e sua conformidade legal uma subordinação unilateral, não apenas adequação, aos interesses da clientela e dos segmentos sociais. O modelo liberal baseia-se tanto na regulação política quanto na inserção social em bases tipicamente mercadológicas, mas, analogamente à administração ortodoxa, o modelo liberal baseia-se na minimização da autonomia burocrática. O diagrama 5 ilustra este efeito dicotômico:

\section{Diagrama 5}

Relações entre política e administração segundo a administração pública liberal

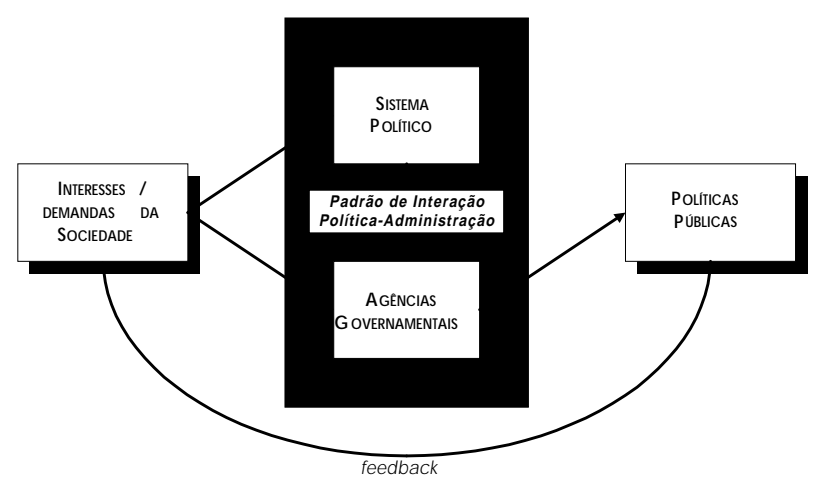


No modelo empreendedor, as instâncias políticas de deliberação valorativa são submetidas à racionalidade predominantemente nas finalidades da clientela, onde se concentra. Este modelo apoia-se essencialmente na inserção social, na construção de canais de acesso da sociedade à burocracia e vice-versa, de forma independente da regulação política e mediante alta autonomia relativa. O diagrama 6 procura traduzir este desequilíbrio entre inserção e regulação:

\section{Diagrama 6}

\section{Relações entre política e administração} segundo a administração pública empreendedora

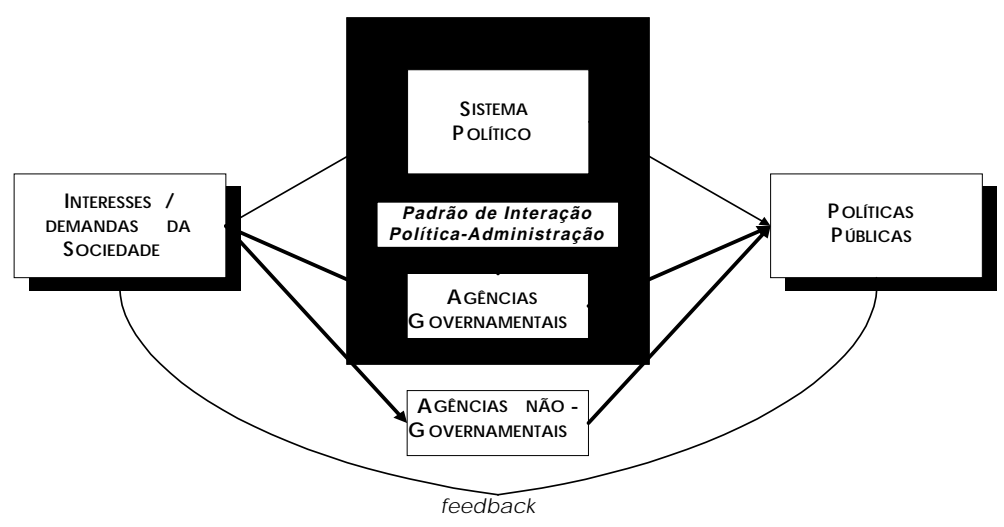

Ambos modelos liberal e empreendedor têm em comum o requisito da inserção, mediante a adequação da utilidade de sua ação para o atendimento das finalidades da clientela. Concentramse, portanto, num requisito de efetividade. A diferença básica está nos mecanismos de identificação da demanda, de agregação de interesses e de definição de clientelas preferenciais, que enquanto no modelo liberal o mercado utiliza o canal político sobre a administração, no modelo empreendedor a administração utiliza o mercado sobre o canal político. No modelo liberal a inserção decorre da imposição de demandas diretamente sobre a administração, que não cabe identificá-las, senão atendê-las mediante estrito controle e desconfiança política. No modelo empreendedor a inserção decorre da imposição de demandas pela administração, à qual cabe identificálas e atendê-las, sobre o sistema político. De outra forma, o modelo empreendedor preconiza que a parcela da atividade pública nãoestatal estará mais distante do controle político, embora mais inserida 
no contexto social. O problema é que em ambos os casos a inserção

é concebida de forma dicotômica, quer pelo sistema político, em detrimento da administração, caso do modelo liberal, quer pela administração, em detrimento do sistema político, caso do modelo empreendedor. Em suma, o modelo do empreededorismo é calcado na inserção social, mas não assegura, e numa boa extensão dificulta, a regulação política. Daí, sua ação dicotomizante, apesar do seu aparente apelo em favor da legitimidade (inserida, precariamente regulada).

\section{A revolução gerencial rumo à pós-gerencial}

A revolução gerencial é portadora de uma seqüência de ensinamentos. Talvez o mais relevante deles seja a convicção de que a burocracia pública é modernizável gerencialmente e passível de inserção social. Certamente que sua qualidade mais ou menos dicotômica, relativamente à regulação política, varia conforme o contexto social, a esfera estatal - a exemplo da regulação política que aproxima-se da inserção social no nível municipal - e o segmento da ação pública - como serviços, por exemplo.

Em relação ao caso brasileiro, esta reflexão é mais que oportuna. A modernização gerencial e a inserção social são certamente um requisito de excelência para as organizações públicas brasileiras, tendencialmente ortodoxas e insuladas. A tendência de inserção social está perfeitamente coadunada com a tendência de consolidação de um padrão de representação de interesses sociais em bases neocorporativas. Mas a construção da regulação política em bases racionais é uma tarefa complexa: esbarra nos imperativos fisiológicos da governabilidade e no bloqueio à burocratização da política - presente, por exemplo na obliteração do papel regulador das comissões parlamentares permanentes em favor das lideranças partidárias. Parece haver um hiato entre o sistema político-representativo e os imperativos de modernização da burocracia pública. Este desequilíbrio pode comprometer a efetividade do processo de modernização da burocracia em bases socialmente inseridas, porque a deficiência da regulação política implica risco de inserções autoorientadas - o que, numa hipótese pessimista, levaria a padrões de neo-insulamento burocrático, ou insulamentos pós-burocráticos.

No nível de análise teórica, a convicção sobre a necessidade de se buscar novos paradigmas no campo das teorias de administração pública decorre não apenas da intensificação das práticas reformistas nos segmentos governamentais em função das 
disfunções burocráticas do estado social contemporâneo. Decorre, também, de uma tomada de consciência teórica que vem se sedimentando a partir da crítica epistemológica às ciências sociais, em particular ao campo da administração pública. A tendência revisionista das teorias de administração pública tem suscitado o surgimento tanto de abordagens sistematizantes, que buscam levantar e repensar o estado da arte sob novas perspectivas, apontando caminhos e explicitando direcionamentos, quanto tem feito surgir abordagens que se propõem alternativas às enquadradas nas correntes predominantes. De uma maneira geral, a trajetória do pensamento no terreno da administração pública tem evoluído no sentido de criar, criticar e aprimorar modelos e princípios de mudança organizacional planejada, nos níveis micro ou macroorganizacional, de um enfoque organizacional para um enfoque político-sociológico, que privilegia como ponto central a tensão entre política e administração (DENHARDT, 1990).

Os paradigmas abordados são tipos-ideais de administração pública. Importa explorar a construção e a análise crítica de paradigmas no sentido de se embasar uma visão de administração pública que não endosse a tradicional dicotomia entre administração e política, entre burocracia e democracia, mas procure se beneficiar de sua integração, em termos de legitimidade da ação pública. Isto não significa advogar em favor de uma linha heterodoxa strictu sensu, baseada na preleção de alternativas conforme as circunstâncias políticas. Também não significa revisar os paradigmas ortodoxo e liberal, mediante um entendimento mais inovador sobre instrumentos de gestão mais adequados e sobre a conduta ética e moral mais apropriada aos burocratas, sob a alegação de que seria preferível se atualizar o paradigma ortodoxo numa ótica de submissão à política, que submeter a política à lógica empresarial da administração pública (MoE, 1994). A boa administração pública é uma possibilidade de implementação organizacional do conjunto das relações político-administrativas do Estado. Isto implica adequação de tecnologia gerencial - não necessariamente disponível sob a forma de um determinado tipo-ideal de administração pública — às finalidades, valores e regras operacionais básicas de cada estado. 
1 A noção de governança aqui se emprega no sentido sugerido por Melo (1996), conforme elaborado por Hollingsworth, Schmitter \& Streeck (1993): "totalidade de arranjos institucionais —incluindo regras e agentes que assegurem o cumprimento dessas regras- que coordenam e regulam transações dentro e fora dos limites de um sistema econômico".

\section{Referências bibliográficas}

Aberbach, Joel; Putnam, Robert \& Rockman, B.A. 1981. Bureucrats and Politicians in Western Democracies. Cambridge: Harvard University Press.

Abrucio, Fernando Luiz. Reforma do Estado e experiência internacional. Brasília, ENAP, mimeo, 1996.

Bendix, Reinhardt. Max Weber: um perfil intelectual. Brasília: UnB, 1986.

Bendor, Jonathan \& MoE, Terry. "An alternative model of bureaucratic politics". American political science review, 1985, 79:755-74.

BenNis, Warren. Beyond bureaucracy. NY: McGraw Hill, 1973.

Bertero, Carlos O. Tipologias e teoria organizacional. ERA 21(1):31-8, jan./mar., 1981.

O Estado brasileiro e a evolução da administração pública: esboço histórico. Brasília: Funcep, mimeo, 1984.

Blau, P. \& ScotT, W. R. Organizações formais: uma abordagem comparativa. São Paulo: Atlas, 1970.

Bresser Pereira, L. Carlos \& Prestes-Motta, Fernando C. Introdução à organização burocrática. São Paulo: Brasiliense, 1980.

CAIDEN, Gerald. Excessive bureucratization: the J-curve theory of bureucracy and Max Weber through the looking glass. In: Farazmand, Ali (org.). Handbook of Bureaucracy. NY: Marcel Dekker, 1994.

Chacon, Vamireh. Max Weber: a crise da ciência e da política. Rio de Janeiro: Forense, 1988.

Collier, D. (org.). O novo autoritarismo na América Latina. Rio de Janeiro: Paz e Terra, 1982.

Coser, Lewis \& Rosenberg, Bernard (orgs.). Sociological theory - a book of readings. New York: McMillan, 1964.

Crozier, Michel. O fenômeno burocrático. Brasília: UnB, 1979.

CUnHA, M. W. V. O sistema administrativo brasileiro. Rio de Janeiro: CEBRAPE, 1963.

Denhardt, Robert. "Public administration theory - the state of the discipline". Public administration - The state of the discipline. Compilado por Naomi Lynn \& Aaron Wildavsky. Chatham: Chatham House Publishers Inc., 1990. 
Dinız, E. \& Lima Jr., O. B. Modernização autoritária: o empresariado e a intervenção do Estado na economia. Rio de Janeiro: IUPERJ, Série Estudos do IUPERJ, n. 47, 1986.

Dobyns, Lloyd \& Crawford-Mason, Clare. Thinking about quality. Progress, wisdom, and the demming philosofy. New York: Times Books-Random House, 1994.

Eisenstadt, S. N. Burocratização e desburocratização. In: CAmpos, Edmundo (org.). Sociologia da burocracia. Rio de Janeiro: Zahar, 1978.

Etzıoni, Amitai. Organizações modernas. São Paulo: Pioneira, 1976.

Evans, Peter. Predatory, Developmental, and other apparatuses: a comparative political economy perspective on the third world state. Sociological Forum, v.4, n.4, 1989.

FARAZMAnd, Ali (org.). Handbook of bureaucracy. NY: Marcel Dekker, 1994.

GARCIA, F. C. "Modernização e reforma administrativa no Brasil: uma interpretação dos impasses e projeto alternativo". Modernização administrativa, coletânea de monografias. Brasília: Ipea, 1978.

Giввs, Christine. "Reinventing government: a mini-forum. Introduction". Public administration review, 1994.

Goodsell, Charles T. "Reinventing government or rediscover it". Public administration review, 1993, 53:85-7.

GoRE, Al. From red tape to results: creating a government that works better and costs less. Washington: National Performance Review, 1993.

Gouldner, Alvin. "Metaphysical pathos and the theory of bureaucracy". Sociological theory - A book of readings. Compilado por Lewis Coser \& Bernard Rosenberg. New York: McMillan, 1964.

Patterns of industrial bureaucracy. London: Routledge \& Kegan Paul, 1954.

GuerreIro-RAmos, Alberto. A nova ciência das organizações. Uma reconceituação da riqueza das nações. Rio de Janeiro: Fundação Getúlio Vargas, 1981. . Administração e contexto brasileiro. Rio de Janeiro: Fundação Getúlio Vargas, 1983.

Holmes, Malcom \& SHAnd, David. Management reform: Some practitioner perspectives on the past ten years". Governance, v.18, n.4.

Ianni, O. Estado e planejamento econômico no Brasil (1930-1970). Rio de Janeiro: Civilização Brasileira, 1977.

Kast, F. E. \& Rosenweig, J. E. Organizations and management. A systems approach. NY: McGraw Hill, 1970.

Leivesley, Robert, CARr, Adrian \& Kouzmin, Alexander. Max Weber: victim of ethnocentric mishandling, or how Weber became a management consultant. In: Farazmand, Ali (org.). Handbook of bureaucracy. NY: Marcel Dekker, 1994.

Lima Jr., O. B. \& Abranches, S. H. H. As origens da crise. Estado autoritário e planejamento no Brasil. Rio de Janeiro: Vértice-IUPERJ, 1987.

Lindblom, Charles E.. O processo de decisão política. Brasília: Universidade de Brasília, Série Pensamento Político, 1980.

Lynn, Naomi \& Wildawsky, Aaron. Public administration - The State of the discipline. Chatham: Chatham House, 1990.

Manheim, Karl. Ideología y utopia. México: Fondo de Cultura Económica, 1949.

MARch, James \& Simon, Herbert A. Teoria das organizações. Rio de Janeiro: FGV, 1967. 
Martins, C. E. Tecnocracia e capitalismo. A política dos técnicos no Brasil. São Paulo: Brasiliense/Cebrap, 1974.

Martins, L. Estado capitalista e burocracia no Brasil pós-64. Rio de Janeiro: Paz e Terra, 1985.

Melo, Marcus André. Governance e reforma do Estado: o paradigma agente x principal. RSP ano 47, v.120, n.1, jan./abr. 1996.

Merton, Robert King. Social theory and social structure. Glencoe: The free Press, 1959.

Michels, Robert. Political parties. Glencoe: The Free Press, 1949.

Mises, Ludwig Von. Bureaucracy. New Haven: Yale University Press, 1944.

MoE, Ronald C.. "The "Reinventing government" Exercise: misinterpreting the problem, misjudging the consequences". Public administration review, 1994, 54:111-22.

Mosher, Frederick. "The public service in the temporary society". Public administration in a time of turbulence. Compilado por Dwight Waldo. Scranton: Chandler Publishers, 1971.

Nascimento, K. T. "Reflexões sobre a estratégia de reforma administrativa: a experiência brasileira". Revista de Administração Pública: 1ํo semestre, 1967.

Nunes, Edson O. Política e insulamento burocrático: a economia política do desenvolvimento brasileiro. Brasília: ENAP (no prelo), 1996.

Modernização, desenvolvimento e serviço público: Notas sobre a reforma administrativa no Brasil. In: Ipea, Perspectivas da economia brasileira. Brasília: Ipea, 1992.

Offe, Clauss. Problemas estruturais do Estado capitalista. Rio de Janeiro: Tempo Brasileiro, 1984.

Osborne, David \& Gaebler, Ted. Reinventando o governo. Como o espírito empreendedor Está transformando o setor público. Brasília: MH Comunicação, 1994.

Parsons, Talcott. The structure of social action. 1937.

Peters, Guy \& Savoie, Donald J. "Civil service reform: misdiagnosing the patient". Public administration review, 1994, 54:418-25.

Pollitt, Christopher. "Managerialism and the public services. The anglo-american experience. Oxford: Basil\&Blackwell, 1990.

PrZeworsky, Adam. Estado e economia no capitalismo. Rio de Janeiro: RelumeDumará, 1995.

On the design of the State: a principal-agent perspective. Artigo distribuído no Seminário internacional "Reforma do Estado na América Latina e no Caribe", Brasília, maio de 1996.

Ramos, N. M. Modernização administrativa e estratégias de mudança: Algumas reflexões sobre o caso brasileiro. Revista de Administração Pública, 15.ed. (extra): p.168-90, 1981

SANTos, Reginaldo \& Ribeiro, Elizabeth M. "A administração política brasileira”. Revista de Administração Pública, v.27, n.4, p.102-35, out./dez. de 1993.

SChwartzman, Simon. "A abertura política e a dignificação da função pública". $O$ estado e a administração pública. Funcep. Brasilia: Funcep, 1987.

Selznick, Phillip. Na Approach to a Theory of Bureaucracy. In: Coser, Lewis \& Rosenberg, Bernard. Sociological theory. NY: McMillan, 1964.

Skidmore, T. (1988) Brasil: de Castelo a Tancredo. 1964-1985. Rio de Janeiro: Paz e Terra. 
Rio de Janeiro: Paz e Terra.

Stillman, Richard J. II. Preface to public administration. New York: St. Martin Press, 1991.

Swiss, James. Adapting total quality management to government. Public administration review, 1992, 52:352-6.

TERry, Larry D.. Why we should abandon the misconceived quest to reconcile public enterpreneurship with democracy. Public administration review, 1993, 53:393-5.

Toffler, Alvin. Rumo à civilização da terceira onda. Diálogo, n.22, vol.14.

Velloso, J. P. R. Modernidade e pobreza: a construção da modernidade econômicosocial. Rio de Janeiro: VI Fórum Nacional, mimeo, 1994.

WAHRLICH, B. M. de S. "A reforma administrativa no Brasil: experiência anterior, situação atual e perspectivas - Uma apreciação geral”. Revista de Administração Pública: v.18, n.1, 1984.

- A reforma administrativa da Era de Vargas. Rio de Janeiro: Fundação Getúlio Vargas, 1983.

WALDO, Dwight. "A theory of public administration means in our times a theory of politics also". Public administration - The State of the discipline. Compilado por Naomi Lynn \& Aaron Wildavsky. Chatham: Chatham House Publishers Inc., 1990.

WEBER, Max. Economy and society - An outline of interpretative sociology. Berkeley: University of California Press, 1978.

. Ensaios de sociologia. Rio de Janeiro, Zahar, 1974.

Wilson, Laura \& Durant, Robert. Evaluating total quality management: the case for a theory driven approach. Public administration review, 1994, 54: 137-46.

WiLson, Wodroow. The study of administration. Political science quarterly, 1887/ 1941, 56:481-506.

Wrong, Dennis. Max Weber. Makers of modern social sciences series. Englewood Cliffs: Prentice Hall, 1970. 


\section{Resumo \\ Resúmen \\ Abstract}

\section{Burocracia e a revolução gerencial — a persistência da dicotomia entre política e administração}

Humberto Falcão Martins

Este ensaio trata da integração entre política e administração no contexto da chamada revolução gerencial. O texto está estruturado em cinco segmentos. Os dois primeiros delineiam uma interpretação weberiana do problema da burocracia: a dicotomização entre política e administração, tanto no nível teórico da governança contemporânea, onde propõe-se um quadro de referência analítica à integração entre política e administração, quanto no contexto da modernização da administração pública brasileira. $\mathrm{O}$ terceiro segmento busca caracterizar os atributos do modelo ideal de administração pública preconizado pela revolução gerencial, a partir da contraposição de outros paradigmas reconstituídos da literatura: um ortodoxo, um liberal, outro empreendedor. O quarto segmento sustenta que os modelos de administração pública preconizados pela revolução gerencial apresentam o mesmo caráter dicotomizante entre política e administração típica da burocracia. O sexto segmento ensaia algumas reflexões sobre a validade da revolução gerencial, sua contribuição para a experiência brasileira e sobre o advento de uma revolução pós-gerencial.

\section{Burocracia y la revolución gerencial - la persistencia de la dicotomía entre política y administración}

\section{Humberto Falcão Martins}

Este ensayo trata de la integración entre política y administración en el marco de la llamada revolución gerencial.

El texto está estructurado en cinco segmentos. Los dos primeros delinean una interpretación weberiana del problema de la burocracia: la dicotomización entre política y administración, tanto en el nivel teórico de la gobernación contemporánea, donde se propone un cuadro de referencia analítica a la integración entre política y administración, como en el contexto de la modernización de la administración pública brasileña. El tercer segmento trata de caracterizar los atributos del modelo ideal de administración pública preconizado por la revolución gerencial a partir de la contraposición de otros paradigmas reconstituidos de la literatura: uno ortodoxo, uno liberal, otro emprendedor. El cuarto segmento sostiene que los modelos de administración pública preconizados por la revolución gerencial presentan el mismo carácter dicotomizante entre política y administración típica de la burocracia. El quinto segmento ensaya algunas reflexiones sobre la validez de la revolución gerencial, su aporte a la experiencia brasileña y sobre la llegada de una revolución postgerencial.
Revista do

Serviço

Público

Ano 48

Número 1

Jan-Abr 1997

Humberto Falcão Martins é mestre em administração pública pela FGV/EBAP e especialista em políticas públicas e gestão governamental no Ministério da Administração Federal e Reforma do Estado 
Bureaucracy and the management revolution - the persistent dichotomy between politics and administration

Humberto Falcão Martins

This essay is addressed to the politics-administration dichotomy in the context of the so called managerial revolution. The text is divided into six parts. Parts 1 and 2 pose a weberian interpretation of the problem of bureaucracy: the politicsadministration dichotomy. This interpretation is applied to the theoretical context of contemporary governance, followed by a proposition of a conceptual framework for politics-administration dichotomy, as well as to the context of the brazilian public administration modernization. Part 3 seeks to characterize a pattern of public administration proposed by the managerial revolution experience by contrasting three different ideal types of public administration: orthodox, liberal and enterpreneurial. Part 4 argues that the public administration paradigm proposed by the managerial revolution carries the same dichotomizing trait presented in typical bureucracy. Part 6 essays some reflections on the validity of the managerial revolution experience as well as its contribution to the brazilian experience and the perspectives of a post-managerial revolution. 